\title{
Mitogenome Phylogeny Including Data from Additional Subspecies Provides New Insights into the Historical Biogeography of the Eurasian lynx Lynx lynx
}

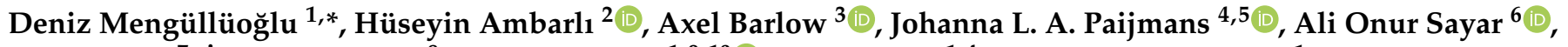 \\ Hasan Emir ${ }^{7}$, İrfan Kandemir ${ }^{8}$, Heribert Hofer ${ }^{1,9,10}{ }^{\infty}$, Jörns Fickel ${ }^{1,4}$ and Daniel W. Förster ${ }^{1}$ \\ check for \\ updates \\ Citation: Mengüllüoğlu, D.; Ambarlı, \\ H.; Barlow, A.; Paijmans, J.L.A.; Sayar, \\ A.O.; Emir, H.; Kandemir, İ.; Hofer, \\ 1 Leibniz Institute for Zoo and Wildlife Research, Alfred-Kowalke-Str. 17, 10315 Berlin, Germany; \\ hofer@izw-berlin.de (H.H.); Fickel@IZW-Berlin.de (J.F.); foerster@izw-berlin.de (D.W.F.) \\ 2 Department of Wildlife Ecology and Management, Faculty of Forestry, Düzce University, \\ Düzce 81620, Turkey; huseyinambarli@gmail.com \\ 3 School of Science and Technology, Nottingham Trent University, Clifton Lane, Nottingham NG11 8NS, UK; \\ axel.barlow.ab@gmail.com \\ 4 Institute for Biochemistry and Biology, University of Potsdam, Karl-Liebknecht-Str. 24-25, \\ 14476 Potsdam, Germany; paijmans.jla@gmail.com \\ 5 Department of Zoology, University of Cambridge, Downing Street, Cambridge CB2 3EJ, UK \\ 6 Department of Game and Wildlife, Cankiri Karatekin University, Cankiri 18100, Turkey; \\ alionursayar@gmail.com \\ 7 Wildlife Department of General Directorate of Nature Conservation and National Parks, Turkish Ministry of \\ Agriculture and Forestry, Ankara 06000, Turkey; hasanemir@gmail.com \\ 8 Department of Biology, Ankara University, Ankara 06000, Turkey; ikandemir@science.ankara.edu.tr \\ 9 Department of Biology, Chemistry and Pharmacy, Freie Universität Berlin, 10315 Berlin, Germany \\ 10 Department of Veterinary Medicine, Freie Universität Berlin, 10315 Berlin, Germany \\ * Correspondence: deniz@izw-berlin.de
}

H.; Fickel, J.; Förster, D.W.

Mitogenome Phylogeny Including Data from Additional Subspecies Provides New Insights into the Historical Biogeography of the Eurasian lynx Lynx lynx. Genes 2021, 12, 1216. https://doi.org/10.3390/ genes12081216

Academic Editor: Carlos Fernandes

Received: 1 July 2021

Accepted: 4 August 2021

Published: 6 August 2021

Publisher's Note: MDPI stays neutral with regard to jurisdictional claims in published maps and institutional affiliations.

Copyright: (C) 2021 by the authors. Licensee MDPI, Basel, Switzerland. This article is an open access article distributed under the terms and conditions of the Creative Commons Attribution (CC BY) license (https:// creativecommons.org/licenses/by/ $4.0 /)$.

\begin{abstract}
Previous molecular studies of the wide-ranging Eurasian lynx Lynx lynx focused mainly on its northern Palearctic populations, with the consequence that the reconstruction of this species' evolutionary history did not include genetic variation present in its southern Palearctic distribution. We sampled a previously not considered Asian subspecies (L. l. dinniki), added published data from another Asian subspecies (L. l. isabellinus), and reassessed the Eurasian lynx mtDNA phylogeny along with previously published data from northern Palearctic populations. Our mitogenome-based analyses revealed the existence of three major clades (A: Central Asia, B: SE Europe/SW Asia, C: Europe and Northern Asia) and at least five lineages, with diversification in Lynx lynx commencing at least $28 \mathrm{kyr}$ earlier than hitherto estimated. The subspecies L. l. isabellinus harbors the most basal matriline, consistent with the origin of Lynx lynx in this subspecies' current range. L. l. dinniki harbors the second most basal matriline, which is related to, and may be the source of, the mtDNA diversity of the critically endangered Balkan lynx L. l. balcanicus. Our results suggest that the Anatolian peninsula was a glacial refugium for Eurasian lynx, with previously unconsidered implications for the colonization of Europe by this species.
\end{abstract}

Keywords: mitogenome; biogeography; intraspecific variation; Caucasian lynx; Balkan lynx; Himalayan lynx; Anatolian refugium

\section{Introduction}

The spatial distribution of terrestrial mammals is determined by the availability of suitable habitat, which has been shaped by historical climatic events and subsequently been modified by anthropogenic land use and land cover change [1]. A consequence of anthropogenic impacts on ecosystems is that a majority of extant terrestrial species that have wide geographic distributions today occur in fragmented and isolated populations 
(e.g., [2-5]). Such fragmentation and isolation enhances the spatial genetic structure generated by (historical) colonization and migration processes, with the consequence that populations harbor variation not present elsewhere [6,7]. In order to obtain a more complete understanding of the evolutionary history of such wide-ranging species, data from small, isolated populations, including those at range margins, must be considered in phylogeographic studies (southern Chinese tiger: [8]; Himalayan wolf: [9]; Himalayan brown bear: [10]). Such small or edge populations may harbor important components of a species' total genetic diversity (clouded leopard: [11,12]; leopard cat [13]; Java sambar: [14]), particularly if refugial populations of former glacial periods have not substantially increased their range (brown bear in the Caucasus: [15]; brown bear in the Himalayas: [10]; Eurasian lynx in the Caucasus: [16]).

Among wild felids, the Eurasian lynx Lynx lynx has the widest distribution in the Palearctic. It inhabits a great variety of biomes with different climatic conditions and displays intraspecific variation in ecological requirements, morphology, and behavior [5], which is signified by six recognized subspecies [17]. Climatic shifts in Asia and climatic and anthropogenic factors in Europe have shaped the species' genetic structure in its recent evolutionary history $[18,19]$. In Northern Asia, populations display clinal variation, while in Europe, recent population extirpation and isolation of small populations have created a heterogeneous, patchy genetic structure across the species' distribution [19]. Historically, western Eurasian lynx populations were better connected and genetically more homogeneous, but in the past two centuries, anthropogenic factors disrupted the formerly existing connectivity among European populations $[19,20]$. As previous molecular studies on L. lynx focused mainly on European and Northern Asian populations [16,18,21-29], most information on the species' phylogeography and evolutionary history derives from these northern Palearctic populations. However, during Pleistocene glaciations, species spreading towards Europe were stopped in their migration by extended ice sheets and remained in glacier-free southern refugia where they accumulated high genetic diversity $[7,30,31]$. These refugia were Iberia, Italy, and the Balkans [32], with the Balkans connecting eastward to Turkey and possibly to the Caucasus $[7,15,33,34]$. Such high genetic diversity was confirmed in L. lynx populations living in Anatolia [35-37] and in the greater Caucasus [16], which renders these populations very important for elucidating the diversity and evolutionary history of Eurasian lynx.

Furthermore, data from L. lynx populations from Central and Eastern Asia would also add essential information to the species' evolutionary history. They live at the edges of the species' range and were not as heavily impacted by climatic oscillations and anthropogenic factors as the northern Palaearctic populations, thus likely maintaining more of their ancestral genetic diversity $[7,38]$. While Eurasian lynx from Mongolia were already included in detailed phylogenetic analyses [18], specimens from other Central Asian (e.g., China and Turkestan) regions were not.

The Caucasian lynx L. l. dinniki populations live in a wide range of habitats and climatic zones, representing almost all European and Western Asian ecosystems ranging from warm Mediterranean to cold alpine regions. They live and reproduce in coniferous forests, and rocky mountains and steppes with no tree cover, and in contrast to their northern conspecifics that prey on ungulates (mostly roe deer), they prey almost exclusively on lagomorphs [39], which were confined to the same refugium during the Pleistocene glaciation [30]. Compared with other Eurasian lynx, individuals of L. l. dinniki are smaller, reflecting the plasticity of Eurasian lynx in ecological and behavioral traits [39-41].

The Himalayan lynx L. l. isabellinus, a subspecies that lives in extreme ecosystems such as high mountains and cold deserts, has already evolved adaptations to these harsh environments that distinguish it from other L. lynx populations in the north [42]. It lives in forested areas of the Pamir and Kunlun Mountains and in Central and Western China and preys on ungulates and lagomorphs, but it is also associated with alpine slopes above tree lines (up to $4200-4500 \mathrm{~m}$ a.s.l.) and high rocky areas of Central Asian deserts with scrub woodland and barrens, where it preys mostly on lagomorphs [42-46]. 
We therefore expect molecular data, in particular, from the Caucasian subspecies L. l. dinniki and the Himalayan subspecies L. l. isabellinus to add important information regarding the evolutionary history of Eurasian lynx. In contrast to the accumulated genetic knowledge about $L$. l. dinniki populations, similar knowledge is not available for $L$. l. isabellinus. The only molecular study available assessed neither its genetic diversity nor its position within the L. lynx phylogeny [38].

Regarding their mitochondrial diversity, Eurasian lynx matrilines have recently [18] been grouped into five haplogroups (HG), of which the most basal, HG1, was represented by L. l. balcanicus, which had split from the other European (L. l. lynx, L. l. carpathicus; HG2,3) and Northern Asian (L. l. wrangeli; HG3-5) subspecies 96.5 thousand years ago (kya). In order to reassess the Eurasian lynx mtDNA phylogeny, we took this already existing dataset [18] and added six mitochondrial genomes (mitogenomes) of L. l. dinniki from three regions in Anatolia, Turkey, one published mitogenome from Northeast China (Khingan Mountains, [47]; L. l. wrangeli [17]), and one published mitogenome from Central China (Tianquan, [38]; L. l. isabellinus [17]). The inclusion of the two additional subspecies (L. l. isabellinus, L. l. dinniki) generated a new dataset that now includes mitogenomes of all six proposed L. lynx subspecies [17]. We discuss our results in the context of the historical distribution of European populations, including the critically endangered Balkan lynx (L. l. balcanicus), as well as in the context of inferring the evolutionary history of this wide-ranging felid species.

\section{Materials and Methods}

\subsection{Sampling}

Between 2012 and 2014, we collected Caucasian lynx (L. l. dinniki) fecal swabs from three regions of the species' Anatolian distribution (Figure 1): the Çı̆̆likara Forest Reserve (ÇK) and the Gidengelmez Mountains (GG; both in Southwest Anatolia), the Nallihan Mountains (NH; in Northwest Anatolia), and the Yusufeli-Kaçkar Mountains in the Lesser Caucasus (YE; in Northeast Anatolia). We also collected two L. l. dinniki hair samples, one from a zoo animal originating from Akseki, Antalya (near the Gidengelmez Mountains), and one from an individual from the Yusufeli-Kaçkar Mountains (Table 1).

Table 1. Numbers and types of samples included in this study per study site.

\begin{tabular}{|c|c|c|c|}
\hline Sampling Location & Area Protection Status & Fecal Swabs & Hair \\
\hline Çı̆̆lıkara Forest Reserve (ÇK) & Research Forest & 2 & - \\
\hline Gidengelmez Mountains (GG) & $\begin{array}{c}\text { Wildlife Development } \\
\text { Reserve }\end{array}$ & 3 & 1 (zoo) \\
\hline Nallıhan Mountains (NH) & Unprotected & 3 & - \\
\hline Yusufeli-Kaçkar Mountains (YE) & $\begin{array}{l}\text { Wildlife Development } \\
\text { Reserve }\end{array}$ & 2 & 1 \\
\hline
\end{tabular}



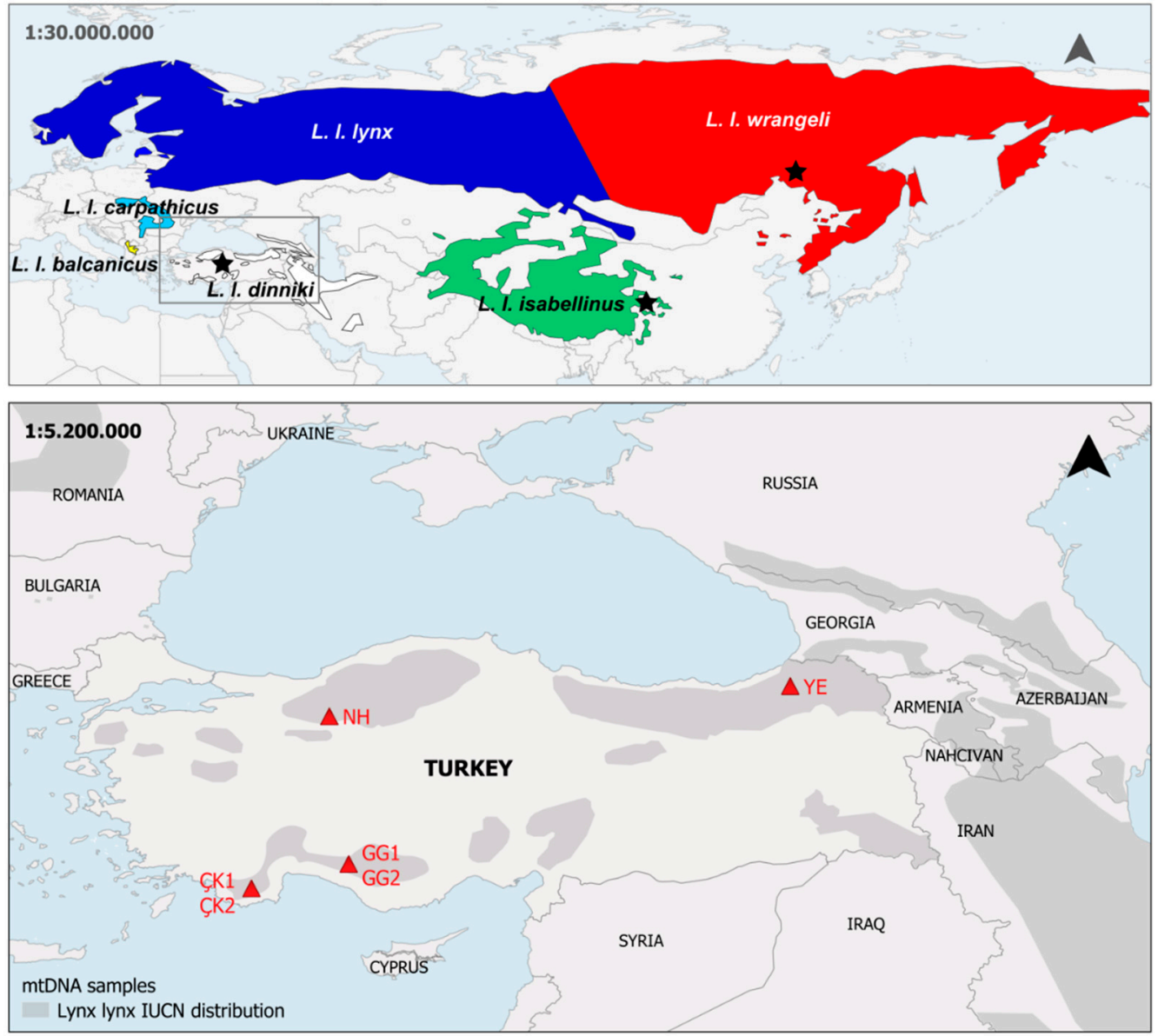

Figure 1. Top: Map of Eurasian lynx subspecies distribution. Stars indicate source area of mitogenomes added to the dataset in [18] (this study; [38,47]). Bottom: Map of Turkey depicting the locations of the four sampling sites for L. l. dinniki in Turkey. These sites are the Çı̆̆lıkara Forest Reserve (ÇK) and the Gidengelmez Mountains (GG) in Southwest Anatolia, the Nallihan Mountains $(\mathrm{NH})$ in Northwest Anatolia, and the Yusufeli-Kaçkar Mountains (YE) in the Lesser Caucasus. Shaded areas indicate the distribution of Lynx lynx [5].

\subsection{DNA Extraction, Library Preparation, and Targeted Capture}

We extracted DNA using a commercially available forensic DNA extraction kit (GENIAL $\mathrm{GmbH}$, Troisdorf, Germany) following the manufacturer's instructions. We then constructed Illumina sequencing libraries using $8 \mathrm{nt}$ indices following a previously established protocol [48]. The libraries were enriched for mitochondrial sequences using hybridization capture. Generation of capture baits also followed an established protocol [49] by using three $\sim 6 \mathrm{~kb}$-long overlapping fragments of the Eurasian lynx mitogenome that were amplified using long-range PCR [50]. Due to the expected degraded nature of the samples' DNA, we performed an in-solution targeted capture at $65^{\circ} \mathrm{C}$ [50]. We then sequenced the mtDNA-enriched libraries using the 150-cycle Reagent Kit v3, generating $75 \mathrm{bp}$ paired-end reads on an Illumina MiSeq (San Diego, CA, USA).

\subsection{Bioinformatic Analysis}

Paired-end reads were de-multiplexed using bcl2fastq v2.17.1.14 (Illumina, Inc. San Diego, CA, USA), followed by adapter sequences removal using cutadapt v1.3 [51]. The minimum overlap length parameter was set to 1 , and match-read-wildcards was enabled. Quality trimming was carried out using the sliding window approach implemented in Trimmomatic [52], with the phred quality threshold set to $Q=20$. Paired adapter-clipped and quality-trimmed reads were then merged using Flash v1.2.8 [53]. Sequences were then 
mapped to a Eurasian lynx reference mitogenome (GenBank acc. no. NC_027083.1) using BWA aln v0.7.10 [54] and samtools v1.19 [55] with default parameters (e.g., seed length of $32 \mathrm{bp}$, mismatch value of 0.04 , reads removed with mapping quality $<\mathrm{Q} 30$ ). Duplicates were marked and removed with MarkDuplicatesByStartEnd.jar. Consensus sequences were generated and annotated in Geneious v8.1.7 [56], with ambiguous bases and bases with a read depth $<5$ being masked with ' $\mathrm{Ns}^{\prime}$. These were manually curated for start and stop codons in coding sequences (CDS) and inspected carefully for potential chimeras indicating Numts. Two repetitive regions of the control region were excluded from further analyses, as they could not be accurately resolved using short Illumina reads.

\subsection{Phylogenetic Analysis}

We aligned the sequenced mitogenomes of the Anatolian L. l. dinniki samples $(n=6$, this study) with 98 Eurasian lynx mitogenome sequences that had previously been published. Ninety-six were from a mitogenome population dataset, covering lynx populations across a wide range of the species' distribution (NCBI PopSet ID: 1799628116; [18]), and two came from individuals sampled in China (one from Tianquan, Central China, acc. no. MH706704, [38]; one from the Khingan Mountains, Northeast China, acc. no. KR919624, [45]). The alignment consisted of 104 sequences and had a length of 16,449 nucleotides (without repetitive sequences in the control region; see above).

The mitochondrial phylogeny and coalescence times were estimated with BEAST v1.8.2 [57], using a coalescent tree prior and assuming a constant population size over the time span of the tree. A strict clock model was used with the per lineage substitution rate fixed to $1.54 \times 10^{-8}$ substitutions/site/year, following Lucena-Perez et al. [18]. An HKY nucleotide substitution model with $\gamma$-distributed rate heterogeneity among sites was also specified. All other parameters and priors were left at their default value. The MCMC chain ran for sufficient time to achieve convergence and adequate sampling of all parameters (ESS > 200), verified using the program Tracer v1.6 [58]. TreeAnnotator [59] was used to remove an appropriate number of burn-in trees, select the maximum clade credibility tree from the posterior sample, and scale node heights to the median of the posterior. The resulting tree was visualized in FigTree v1.4.4 (http:/ / tree.bio.ed.ac.uk/software/figtree/ accessed on 25 November 2020).

A median-joining network of the 104 mitogenome sequences was constructed using PopArt v1.7 [60].

\section{Results}

Out of the twelve Anatolian samples, we recovered complete or nearly complete mitochondrial genomes for six samples with a $\geq 5 \times$ sequencing depth at each base (Table 2 ). The number of missing positions per sequence ranged from 0 to 1760 (mean $=475)$, and each sample had a distinct haplotype.

Table 2. Summary of sequencing results following targeted capture for the six Anatolian samples with complete or near-complete mitogenomes.

\begin{tabular}{ccccccc}
\hline Sample ID & Sample Type & Raw Reads & $\begin{array}{c}\text { Joined Read } \\
\text { Pairs after } \\
\text { Quality } \\
\text { Trimming }\end{array}$ & $\begin{array}{c}\text { Percent } \\
\text { Duplication } \\
\text { Percentage }\end{array}$ & $\begin{array}{c}\text { Deduplicated } \\
\text { Mitogenome } \\
\text { Coverage at } \\
\geq \text { 5 } \times \text { Excl. } \\
\text { Repetitive } \\
\text { Region }\end{array}$ \\
\hline NH & Fecal swab & $4,212,534$ & $1,613,945$ & $94.02 \%$ & 28,279 & 100 \\
ÇK1 & Fecal swab & $1,682,350$ & 557,712 & $84.29 \%$ & 15,366 & 98.78 \\
GG1 & Fecal swab & $1,797,014$ & 569,045 & $78.95 \%$ & 13,174 & 97.62 \\
GG2 & Fecal swab & $11,647,032$ & $4,271,917$ & $98.20 \%$ & 31,521 & 100 \\
YE & Hair (zoo) & $1,215,728$ & 349,044 & $86.96 \%$ & 6727 & 10,080 \\
\hline
\end{tabular}




\subsection{General mtDNA Phylogeny}

Phylogenetic analysis of the alignment (104 sequences) revealed three well-supported clades (posterior support: 0.92-1), henceforth termed A, B, and C (Figure 2). Based on current subspecies delineation [17], Eurasian lynx clade A harbors one subspecies only, the Himalayan lynx L. l. isabellinus [38]. As this clade contains one sequence only, variability within this clade remains unknown. Clade B is formed by two subspecies: the Caucasian lynx L. l. dinniki and the Balkan lynx L. l. balcanicus. Clade C, by far the most variable of the three clades based on the sequences available, comprises three subspecies: the European lynx L. l. lynx, the Carpathian lynx L. l. carpathicus, and the Siberian lynx L. l. wrangeli (Figure 2).

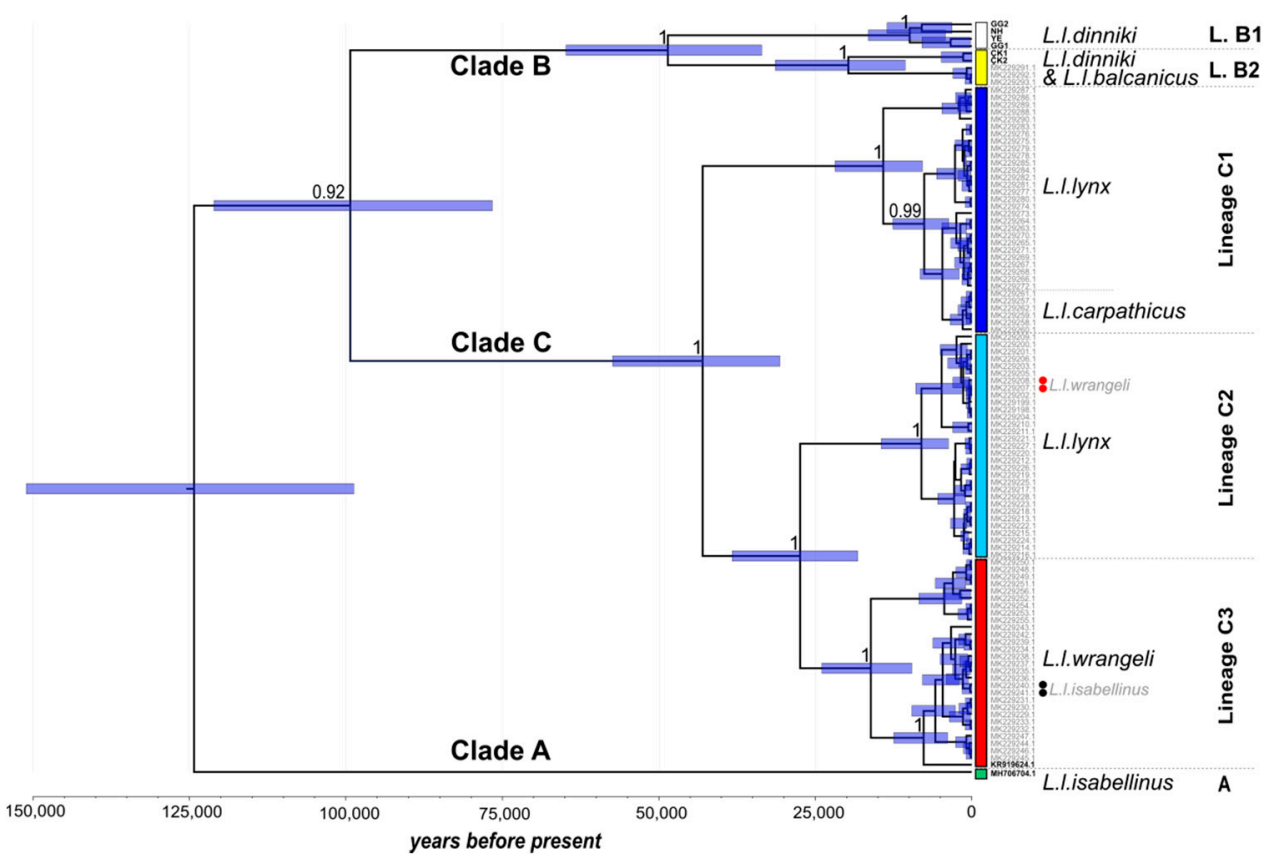

Figure 2. Bayesian phylogenetic tree of L. lynx mitogenome sequences. Posterior node support is given for all nodes with values $>0.9$. Blue bars at nodes indicate the $95 \%$ credibility intervals for coalescence times in years ( $x$-axis). The three main branches are labeled according to clade assignment; lineage and subspecies assignment is indicated on the right. Vertical colored bars mark lineages, which are separated by dashed horizontal lines. Sequences are labeled by either GenBank accession number $[18,38,47]$ or by location (L. l. dinniki). Red dots mark two L. l. wrangeli individuals within lineage C2 (see text for explanation); black dots indicate the two erroneously labeled $L$. $l$. isabellinus individuals in lineage $\mathrm{C} 3$.

As we report new Eurasian lynx matrilines, including several basal ones, we adopt a new terminology based on a hierarchical structure of clades and lineages (Table 3) in order to avoid confusion with the previously published terminology [18].

Table 3. MtDNA clades, lineages, and haplogroups of six Eurasian lynx subspecies ${ }^{\text {a }}$ revealed in our study and what they correspond to in Lucena-Perez et al. [18].

\begin{tabular}{|c|c|c|c|c|}
\hline $\begin{array}{c}\text { Therminology Used in } \\
\text { This Study }\end{array}$ & $\begin{array}{l}\text { Subspecies Included: } \\
\text { Lynx lynx }\end{array}$ & Origin & $\begin{array}{c}\text { Corresponds to } \\
\text { Haplogroup (HG) }\end{array}$ & $\begin{array}{l}\text { Subspecies Included: } \\
\qquad \operatorname{Lynx} \operatorname{lyn} x\end{array}$ \\
\hline Clade A & isabellinus & Southern China & - & - \\
\hline Clade B & dinniki, balcanicus & & HG 1 & balcanicus \\
\hline lineage B1 & dinniki & $\begin{array}{l}\text { Turkey (SW, NW, and } \\
\text { NE Anatolia) }\end{array}$ & - & - \\
\hline lineage B2 & dinniki, balcanicus & $\begin{array}{l}\text { Turkey (SW Anatolia), } \\
\text { Montenegro, Serbia }\end{array}$ & HG 1 & balcanicus \\
\hline
\end{tabular}


Table 3. Cont.

\begin{tabular}{|c|c|c|c|c|}
\hline $\begin{array}{c}\text { Therminology Used in } \\
\text { This Study }\end{array}$ & $\begin{array}{l}\text { Subspecies Included: } \\
\text { Lynx lynx }\end{array}$ & Origin & $\begin{array}{c}\text { Corresponds to } \\
\text { Haplogroup (HG) }\end{array}$ & $\begin{array}{l}\text { Subspecies Included: } \\
\text { Lynx lynx }\end{array}$ \\
\hline Clade C & $\begin{array}{c}\text { lynx, carpathicus, } \\
\text { wrangeli }\end{array}$ & & HG 2-5 & $\begin{array}{c}\text { lynx, carpathicus, } \\
\text { wrangeli, isabellinus c }\end{array}$ \\
\hline \multirow[t]{2}{*}{ lineage $\mathrm{C} 1$} & $\operatorname{lyn} x$ & $\begin{array}{l}\text { NE Poland, Latvia, } \\
\text { Russia (Kirov, Ural) }\end{array}$ & \multirow[t]{2}{*}{ HG 2} & lynx, carpathicus \\
\hline & carpathicus & $\begin{array}{l}\text { S Poland, Slovakia, } \\
\text { Romania }\end{array}$ & & \\
\hline lineage $\mathrm{C} 2$ & lynx, wrangeli ${ }^{\mathrm{c}}$ & $\begin{array}{c}\text { Norway, Russia (Kirov, } \\
\text { Ural, Yakutia) }\end{array}$ & HG 3 & lynx, wrangeli ${ }^{\mathrm{c}}$ \\
\hline \multirow[t]{2}{*}{ lineage $\mathrm{C} 3$} & wrangeli & $\begin{array}{c}\text { Russia (Primorsky Krai, } \\
\text { Yakutia, Tuva) }\end{array}$ & \multirow[t]{2}{*}{ HG 4, 5} & \multirow[t]{2}{*}{ wrangeli, isabellinus $\mathrm{d}$} \\
\hline & Isabellinus $^{\mathrm{d}}$ & Mongolia (Ömgönovi) & & \\
\hline
\end{tabular}

a: Subspecies assignment follows Kitchener et al. [17]. ${ }^{\mathrm{b}}$ [18]. ${ }^{\mathrm{c}}$ These two L. l. wrangeli individuals are likely introgressed with L. l. lynx mtDNA as their nuclear genomes are L. l. wrangeli. ${ }^{d}$ Two lynx samples from Mongolia have been listed as L. l. isabellinus ([18]; Acc.no. MK229240, -41), but both mitogenome and WGS analysis assigned these samples to L. l. wrangeli [18]. Thus, the assignment of L. l. isabellinus to HG5 is erroneous. We included these two sequences in our analysis, in which they grouped with L. l. wrangeli (black dots in lineage C3, Figure 2).

\subsection{History of $m t D N A$ Clades and Lineages}

Clade A: This basal clade (Figure 2, green) had diverged 124 thousand years ago (kya; $\mathrm{CI}_{95}$ : 151-98 kya) at the beginning of the Late Pleistocene from the most recent common ancestor (MRCA) of all three Eurasian lynx clades.

Clades B and C: About $25 \mathrm{ky}$ later ( 99 kya, $\left.\mathrm{CI}_{95}: 121-77 \mathrm{kya}\right)$, clades B and C diverged from their MRCA.

Lineages B1 and B2: About 49 kya ( $\mathrm{CI}_{95}$ : 74-34 kya), clade B split into two lineages: lineage B1 (Figure 2, white bar) and lineage B2 (Figure 2, yellow bar; corresponding to 'haplogroup $1^{\prime}$ from [18], Table 3). The former contains sequences from L. l. dinniki only $(n=4)$, while the latter is formed by both L. l. dinniki $(n=2$, bold font) and L. l. balcanicus $(n=3)$, rendering L. l. dinniki paraphyletic in this analysis. Within L. l. dinniki, lineage B1 is present in three sampling sites, while B2 is present only in one site (Çı̆̆lıkara Forest Reserve, in Southwest Anatolia). The divergence time between L. l. dinniki and L.l. balcanicus within lineage $\mathrm{B} 2$ is only $\sim 20 \mathrm{ky}\left(\mathrm{CI}_{95}: 31-11 \mathrm{ky}\right)$.

Lineages C1-C3: About 43 kya ( $\mathrm{CI}_{95}$ : 57-31 kya), lineage C1 (Figure 2, dark blue bar) split from the MRCA of lineages C2 (Figure 2, bright blue bar) and C3 (red bar). Lineage C1 (corresponding to the former HG2 [18]) harbors both the European lynx (L. l. lynx) with individuals coming from Poland, Latvia, and the European part of Russia, and the Carpathian lynx (L. l. carpathicus). The latter individuals carry an L. l. carpathicus-specific haplotype that is not present in L. l. lynx individuals from lineage $\mathrm{C} 1$ (indicated in Figure 2). The youngest lineages to emerge were $\mathrm{C} 2$ and $\mathrm{C} 3$, which diverged about $27 \mathrm{kya}\left(\mathrm{CI}_{95}\right.$ : 38-18 kya) from their MRCA. Lineage C2 (former HG3 [18]) consists of two larger clusters, one exclusively formed by L. l. lynx mitogenomes from Scandinavia (Norway), and the second one predominantly formed by L. l. lynx mitogenomes from the European part of Russia (Kirov region, Ural). Thus, L. l. lynx appears in two lineages (C1 and C2), whereby not all descendants (L. l. lynx and L. l. carpathicus) share the same mitochondrial MRCA, rendering L. l. lynx mitochondrial lineages paraphyletic. The second cluster of lineage C2 contains two sequences (Figure 2, lineage C2, red dots) from individuals sampled in the Yakutsk region (Russian Far East; acc. nos.: MK229207, -208), which, based on their geographic origin and nDNA background, were assumed to be Siberian lynx L. l. wrangeli [16]. However, as these individuals carry L. l. lynx mtDNA but also L. l. wrangeli nuclear DNA, we consider them Siberian lynx introgressed with L. l. lynx mtDNA, which renders the mtDNA lineage C2 an L. l. lynx-specific lineage. Lineage C3 (former HGs 4 and 5 [18]) consists of lynx from only one subspecies as well: the Siberian lynx L. l. wrangeli. Within lineage C3, two individuals labeled as L. l. isabellinus (in [18]) 
were also included in our analysis (Figure 2, black dots). However, given their sampling locality (Ömnögovi, southern Mongolia), their assignment to the Himalayan lynx can be excluded [17]. We do not assume introgression of mtDNA into another subspecies here because the assignment to L. l. wrangeli was not solely based on mtDNA but was confirmed by nuclear DNA data that were also indicative for L. l. wrangeli [18]. Therefore, we consider lineage $\mathrm{C} 3$ to be an L. l. wrangeli-specific lineage. Another interesting observation regarding clade $C$ is the onset of diversification in all three lineages $~ 15-10$ kya (transition from Pleistocene to Holocene and end of glaciation), indicating rapid population expansion around that time. Finally, the presence of the two L. l. wrangeli individuals in lineage C2 (Figure 2, red dots), as mentioned above, would also render L. l. wrangeli (in addition to L. l. lynx) paraphyletic in this phylogeny.

A large number of nucleotide differences corroborate the deep separation of the three Eurasian lynx clades, as visualized in the haplotype network (Figure 3a). The divergence appears most pronounced for clade A, with 35 mutations separating L. l. isabellinus from the putative most recent common ancestor of all three Eurasian lynx clades (Figure 3a, central white diamond). Yet, the branches leading to clades $B$ and $C$ also feature numerous mutations, exemplifying a fast accumulation of mutations within these lynx clades and lineages in the last $100 \mathrm{ky}$. Seventeen mutations separate the MRCA (Figure 3a, left red diamond) of lineages B1 (four haplotypes) and B2 (three haplotypes) from the putative Eurasian lynx MRCA haplotype, while 14 nucleotide changes separate the MRCA of all clade $C$ lineages (24 haplotypes) from the putative Eurasian lynx MRCA haplotype (Figure 3a, right red diamond). The haplotype network shows a peculiar structure for lineage $\mathrm{C} 1$ (seven haplotypes; Figure 3a). This structure is not a matter of sample size because lineages $C 2$ and $C 3$ have similar sample sizes. However, while all other lineages (including B1 and B2) have either a tree-like or a star-like haplotype structure, lineage C1 (consisting of six L. l. lynx haplotypes and one L. l. carpathicus haplotype) deviates from this by having a cube-like structure.

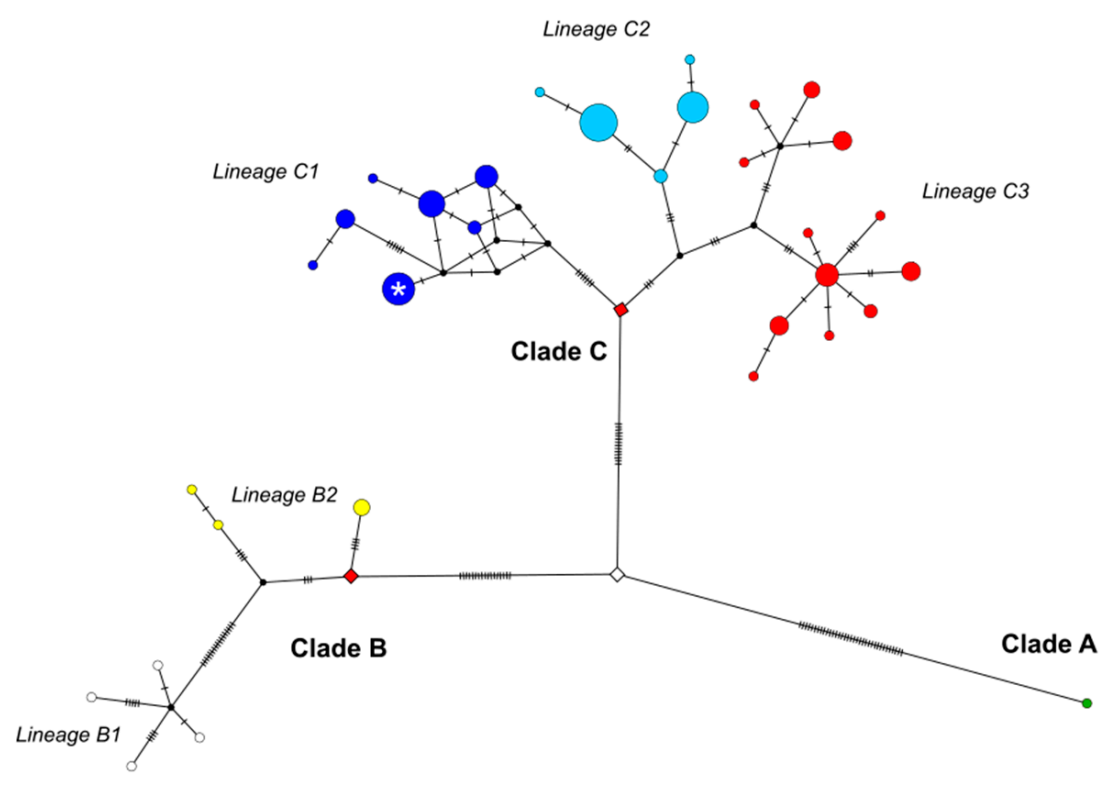

Figure 3. Cont. 
(b)

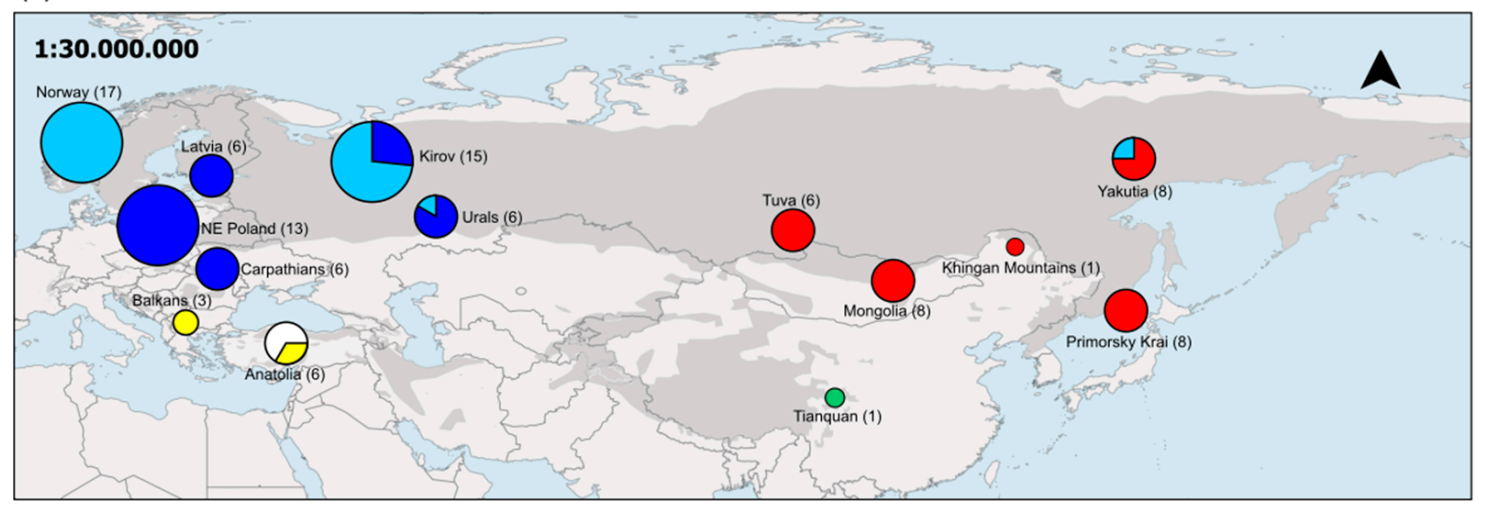

Figure 3. Relationships among L. lynx mitogenomes and their geographic distribution. (a) Median-joining network of L. lynx mitogenome haplotypes. Each circle represents a haplotype, with the circle size indicating the number of individuals sharing that haplotype. Black dots (vectors) were introduced by the network constructing algorithm and represent haplotypes not sampled. Dashes along lines that connect haplotypes indicate the number of nucleotide differences between haplotypes. Coloring of lineages follows Figure 2. Diamond-shaped symbols indicate the most recent common ancestors (MRCA), white: MRCA of all clades, red: MRCA for lineages. The white star in lineage C1 indicates the L. l. carpathicus-specific haplotype. (b) Geographic distribution of L. lynx mitogenomes across the Palearctic region. Coloring of circles follows Figure 2 and indicates clade/lineage assignment, circle size indicates number of individuals included. The figure was adapted from Lucena-Perez et al. [18] and extended to include L. l. dinniki (Anatolia, $n=6$ ), L. l. wrangeli from China (Khingan Mountains, $n=1$ [47]), and L. l. isabellinus (Tianquan, $n=1$ [38]).

\section{Discussion}

Our results indicate that southern Palearctic populations of Eurasian lynx harbor mitochondrial diversity not present in more northerly populations. Moreover, sampling of small populations at range margins in Anatolia (L. l. dinniki; this study) and China (L. l. isabellinus; [38]) revealed important relationships among matrilines in Eurasian lynx, contributing to our knowledge regarding more basal relationships within this species.

These two subspecies (L. l. dinniki and L. l. isabellinus) not previously considered in phylogenetic analyses of complete mitogenomes are among the most basal in our phylogenetic reconstruction, together with L. l. balcanicus (Figure 2). Large areas of their distributions in the southern Palearctic are still unsampled, and their diversity is still largely uncharacterized (Figure $3 b$ ). As demonstrated here, targeted capture of mtDNA sequences from non-invasively collected sample material may be one approach to obtain such mtDNA data.

\subsection{Mitogenome Phylogeny}

Clade A: The inclusion of the Himalayan lynx L. l. isabellinus into the matrilinear phylogeny of the Eurasian lynx revealed the presence of at least one additional (older) clade in the mtDNA variability of the species (Figure 2). It also shifted the previous age estimate for the first split within this species by approximately 28,000 years: from $\sim 96.5 \mathrm{ky}\left(\mathrm{CI}_{95}: 122-73 \mathrm{ky}\right.$; [18]) to at least $124 \mathrm{ky}\left(\mathrm{CI}_{95}: 151-98 \mathrm{ky}\right)$. Unfortunately, clade $\mathrm{A}$ is represented by only a single individual in our analysis. Thus, we do not know the extent of variability within this clade. However, as clade A is basal in the Eurasian lynx phylogeny, we expect mtDNA variability to be large in this clade. In addition, its basal position in the phylogeny points to Central Asia as the likely origin for Eurasian lynx, supporting previous hypotheses [61]. We also included another Chinese L. lynx sample in our phylogeny, collected $\sim 3200 \mathrm{~km}$ northeast of the sampling site of L. l. isabellinus [38]. The mitogenome of this sample (acc.no. KR919624; [45]) is placed in lineage C3 (Figure 2, acc.no. in bold; L. l. wrangeli; Figure 3b, Khingan Mountains), thereby indirectly confirming the Central Asian/Southern China distribution range of L. l. isabellinus [17]. 
Clade B: Inclusion of the Caucasian lynx L. l. dinniki did not change the inferred age of the divergence of clades B and C from their MRCA (Figure 2). Our estimate of $99 \mathrm{ky}$ $\left(\mathrm{CI}_{95}: 121-77 \mathrm{ky}\right)$ is very similar to the previous estimate of $96.5 \mathrm{ky}\left(\mathrm{CI}_{95}: 122-73 \mathrm{ky}\right.$; [18]). The inclusion of L. l. dinniki had a striking impact on the relative position of L. l. balcanicus (basal 'HG1' in [18]). While the inclusion of L. l. isabellinus (clade A) caused the Balkan lynx to lose its basal position in the phylogeny, the inclusion of L. l. dinniki shifted the position of L. l. balcanicus further. The new phylogeny shows a deep $\sim 49$-ky-old split in clade B (the deepest within any clade) leading to the emergence of clade B lineages B1 and B2 (Figure 2). The striking change in the placement of L. l. balcanicus is that instead of comprising its own separate lineage, it diverged within lineage B2 from L. l. dinniki approximately 20 kya, shortly after the last glacial maximum (LGM: 22 kya; [7]). There are three possible scenarios to explain these new results.

- Scenario 1: The Balkan lynx is a true subspecies, but the three Balkan lynx included in our analysis (from [18]) were descendants of a former hybridization event between L. l. balcanicus (male) and L. l. dinniki (female) and thus introgressed with L. l. dinniki lineage B2 mtDNA. Such introgressions occurred in other species, particularly if conspecific partners were scarce [62-64].

- $\quad$ Scenario 2: The entire lineage B2 is actually an L. l. balcanicus lineage that emerged $\sim 48$ kya from an MRCA with L. l. dinniki and had split into two sublineages 20 kya, whereby ancestors of the two L. l. dinniki individuals from lineage B2 (ÇK1 and ÇK2; Figure 2) became introgressed with mtDNA from one of the two L. l. balcanicus sublineages. It needs to be noted that these two subspecies live on either side of the Bosporus junction between Asia (i.e., L. l. dinniki) and Europe (i.e., L. l. balcanicus), a junction that, during the evolution of these lineages, could have been traversed by either subspecies across the land masses connecting Asia and Europe via the Dardanelles and the Bosporus $[65,66]$.

- $\quad$ Scenario 3: The Balkan lynx is not a true subspecies but belongs to L. l. dinniki [18,38].

- Even though the three scenarios differ in their parsimony, with scenario 3 being the most parsimonious, all three are feasible in principle and consistent with the data.

Clade C: Shortly after clade B had diverged into two lineages ( 48 kya), clade C also diverged ( $\sim 43 \mathrm{kya})$. There are two peculiarities to this clade. The first is that lineage C1 harbors two subspecies, namely, L. l. lynx and L. l. carpathicus, while the other two lineages of this clade, lineages C2 (L. l. lynx) and C3 (L. l. wrangeli), consist of single subspecies only (neither considering the introgressed L. l. wrangeli in lineage C2, nor the wrongly 'L. l. isabellinus'-labeled lynx in lineage C3). All six Carpathian lynx included in lineage $\mathrm{C} 1$ shared the same subspecies-specific haplotype (Figure 3a). This Carpathian lynx haplotype has an estimated age of 5 ky only $\left(\mathrm{CI}_{95}: 8-2 \mathrm{ky}\right.$; Figure 2), a period too short for subspeciation even when considering that this estimate is based on just a single haplotype. This age is also much younger than the onset of diversification in the three clade C lineages (15-10 kya). A plausible explanation for the young age of this haplotype is an L. l. lynx origin. As the analysis of ancestral nuclear genotypes demonstrated Carpathian lynx-specific nDNA genotypes without signs of admixture [18], such an introgression scenario seems very likely. As Carpathian lynx form a small and isolated population [67] that is of high conservation value, it needs to be determined if introgression is a problem for this lynx subspecies as it is for the Scottish wildcat Felis silvestris [68].

The second peculiarity of clade $C$ is the mitogenome distribution of L. l. lynx. The European lynx is the only L. lynx subspecies with mitogenomes occurring in two lineages ( $\mathrm{C} 1$ and $\mathrm{C} 2$ ) with considerable divergence ( $43 \mathrm{ky})$, the unresolved subspecies assignment in lineage B2 notwithstanding (see above). For L. l. lynx, three ancestral nDNA clusters have been reported [18], one of which occurs only in NE Poland (harboring mtDNA lineage C1), and another of which occurs only in Norway (harboring mtDNA lineage C2). The third nDNA cluster is present in Kirov and the Ural Mountains, where both mtDNA lineages ( $\mathrm{C} 1$ and $\mathrm{C} 2)$ are found. European lynx from Latvia included in the analysis (all belonging to mtDNA lineage $\mathrm{C} 1$ ) show an admixed nuclear genome between European 
lynx from Western Russia (Kirov, Ural) and NE Poland [18]. Thus, it is possible that mitogenomes of L. l. lynx from the European part of Russia have introgressed into the Central European L. l. lynx population. This scenario would result in a match between genotypes and haplotypes, emphasizing the distinctiveness of L. l. lynx in lineages $\mathrm{C} 1$ and $\mathrm{C} 2$, both in terms of their nDNA and their mtDNA.

\subsection{Implications for European Populations of Lynx lynx}

In the context of the published nuclear genomic data [18], our results indicate at least four colonization waves of Europe by Eurasian lynx. There was one southern wave by individuals of clade $\mathrm{B}$ and three northern ones by individuals of lineages $\mathrm{C} 1$ and $\mathrm{C} 2$ (we are not considering L. l. carpathicus here as we believe them to be introgressed with L. l. lynx mtDNA; see above). One of these northern waves led to the establishment of the Scandinavian population (i.e., Norway, lineage C2 only, HG3 in [18]), another one led to the establishment of L. l. lynx populations in Central Europe (i.e., NE Poland, lineage C1, HG2 in [18]), and the third one led to the establishment of populations in the European part of Russia and the Baltic states (i.e., Kirov, Ural, Latvia, lineage C1, HG2 in [18]). Lynx from the latter two waves formed a genotypic suture zone likely running through the Baltic region.

Besides the detection of a new clade in the mtDNA phylogeny (clade A: L. l. isabelli$n u s)$, the most striking result of the new analysis was the phylogenetic repositioning of L. l. balcanicus. Independent of the three scenarios outlined above, our study reveals a very close association of Balkan lynx with Caucasian lynx L. l. dinniki from Southwest Anatolia, thereby confirming analyses of mitochondrial cytb and d-loop fragments that had previously suggested such association [35]. Clade B likely colonized Europe along a southern route. This route was probably via the Bosphorus junction, as it has been inferred for other species $[15,33,69,70]$. This could explain why the diversification in clade $B$ preceded the one in clade $C$ by $\sim 5 \mathrm{ky}$ (Figure 2 ), as post-glacial expansions in southern regions were possible earlier than in the northern regions.

The southern Palearctic contribution to European lynx populations is also highly relevant regarding the current and future status of the critically endangered Balkan lynx L. l. balcanicus. Thus far, the nuclear genomes of L. l. dinniki and L. l. balcanicus have not yet been compared, and thus the true status of the latter remains unresolved. In this regard, the Southwest Anatolian population of the Caucasian lynx is of particular interest, as this harbors the matriline (B2) present in the Balkan lynx sampled thus far. Future efforts to supplement L. l. balcanicus populations with lynx from elsewhere need to take the possibility of a partial southern Palearctic ancestry (i.e., L. l. dinniki) into account.

\subsection{Anatolia as a Hotspot of Diversity}

Being positioned at the junction of Europe, Asia, and Africa, and having been influenced by glacial maxima only peripherally, Anatolia is a diversity hotspot for both endemic and widely distributed terrestrial organisms [71]. This diversity also extends to the genetic diversity within these species. In addition to the Eurasian lynx, for which multiple lineages and haplotypes are present in Anatolia, previous studies have demonstrated that Anatolia harbors extensive intraspecific diversity in many other terrestrial mammals, among them the brown bear [15], the gray wolf [72], the red fox [73], the marbled polecat [74], the stone marten [34], the ground squirrel [75], the brown hare [69,70], and the house mouse [76]. Molecular genetic studies of taxa in Anatolia thus provide valuable information about how biodiversity is generated and maintained in many species, as well as providing a framework to address current conservation needs for a host of threatened and endangered species (e.g., mountain and sand gazelles [77], leopard [78]).

\section{Conclusions}

Unfortunately, most studies on the ecology or the genetics of the Eurasian lynx have been conducted on populations in the northwestern (i.e., European) portion of its distribution, with a few exceptions $[17,18,37-39,41-44,79]$. Our mitogenome-based phylogeny 
reveals that two Asian subspecies that have gone relatively unstudied, L. l. dinniki and L. l. isabellinus, harbor two basal matrilines. This result is perhaps not unexpected considering an Asian origin of this species [61] and emphasizes the need to address the paucity of data for these two subspecies in order to improve our understanding of the evolutionary history and ecology of this species.

Of course, mitochondrial sequences are only a single genetic marker which does not capture the complexity of the evolution of the nuclear genome. This can lead to erroneous conclusions due to, for example, incomplete lineage sorting or introgression (e.g., [14,80]). We tried to avoid these pitfalls by considering introgression events in the interpretation of our results. We strongly encourage follow-up studies on L. l. dinniki and L. l. isabellinus employing nuclear genomic data, to be analyzed together with equivalent data available for the other subspecies.

Author Contributions: Conceptualization, D.M., J.F., D.W.F.; sampling, H.A., D.M., H.E., A.O.S.; analysis, D.M., A.B., J.L.A.P., D.W.F.; writing-original draft preparation, D.M., J.F., D.W.F.; writing-review and editing, A.B., J.L.A.P., H.A., A.O.S., H.E., İ.K., H.H., D.M., J.F., D.W.F.; visualization, D.M., J.F., D.W.F.; supervision, H.H., J.F., D.W.F.; project administration, D.M., H.H., D.W.F. All authors have read and agreed to the published version of the manuscript.

Funding: Accommodation for DM in Nallhhan was partially provided by Nallihan Turizm Gonulluleri Dernegi and per diems by the General Directorate of Nature Conservation and National Parks (NCNP), Turkish Ministry of Agriculture and Forestry. Sample collection in Ankara was supported by the RSGF 11447-1 project. DM was also supported by a DAAD grant and a Leibniz-IZW research grant. Support for field work in Antalya was provided by the TÜBITAK MAM-NCNP project 109G016 for Conservation and Management of Large Mammals in Turkey.

Institutional Review Board Statement: Not applicable.

Informed Consent Statement: Not applicable.

Data Availability Statement: Sequences are deposited in GenBank under the following accession nos.: MZ672021-MZ672026.

Acknowledgments: We would like to thank the managers and employees of the General Directorate of Nature Conservation and National Parks and its provincial directorates in Ankara, Artvin, and Antalya.

Conflicts of Interest: The authors declare no conflict of interest.

\section{References}

1. Newbold, T.; Hudson, L.N.; Arnell, A.P.; Contu, S.; De Palma, A.; Ferrier, S.; Hill, S.L.L.; Hoskins, A.J.; Lysenko, I.; Phillips, H.R.P.; et al. Has Land Use Pushed Terrestrial Biodiversity beyond the Planetary Boundary? A Global Assessment. Science 2016, 353, 288-291. [CrossRef]

2. Reading, R.; Michel, S.; Amgalanbaatar, S. Ovis ammon. The IUCN Red List of Threatened Species 2020: e.T15733A22146397. Available online: https:/ / dx.doi.org/10.2305/IUCN.UK.2020-2.RLTS.T15733A22146397.en (accessed on 21 June 2021).

3. McLellan, B.N.; Proctor, M.F.; Huber, D.; Michel, S. Ursus Arctos (Amended Version of 2017 Assessment). The IUCN Red List of Threatened Species 2017: e.T41688A121229971. Available online: https:/ /dx.doi.org/10.2305/IUCN.UK.2017-3.RLTS.T41688A1 21229971.en (accessed on 21 June 2021).

4. Avgan, B.; Henschel, P.; Ghoddousi, A. Caracal caracal. The IUCN Red List of Threatened Species 2016: e.T3847A50650230. Available online: https:/ /dx.doi.org/10.2305/IUCN.UK.2016-2.RLTS.T3847A50650230.en (accessed on 31 May 2021).

5. Breitenmoser, U.; Breitenmoser-Würsten, C.; Lanz, T.; von Arx, M.; Antonevich, A.; Bao, W.; Avgan, B. Lynx lynx (Errata Version Published in 2017). The IUCN Red List of Threatened Species 2015: e.T12519A121707666. Available online: https: / / www.iucnredlist.org/species/12519/121707666 (accessed on 31 May 2021).

6. Frankham, R.; Ballou, J.D.; Briscoe, D.A. Introduction to Conservation Genetics; Cambridge University Press: Cambridge, UK, 2002; p. 480.

7. Hewitt, G.M. Speciation, Hybrid Zones and Phylogeography-Or Seeing Genes in Space and Time. Mol. Ecol. 2001, 10, 537-549. [CrossRef] [PubMed]

8. Wilting, A.; Courtiol, A.; Christiansen, P.; Niedballa, J.; Scharf, A.K.; Orlando, L.; Balkenhol, N.; Hofer, H.; Kramer-Schadt, S.; Fickel, J.; et al. Planning Tiger Recovery: Understanding Intraspecific Variation for Effective Conservation. Sci. Adv. 2015, 1, e1400175. [CrossRef] 
9. Werhahn, G.; Liu, Y.; Meng, Y.; Cheng, C.; Lu, Z.; Atzeni, L.; Deng, Z.; Kun, S.; Shao, X.; Lu, Q.; et al. Himalayan Wolf Distribution and Admixture Based on Multiple Genetic Markers. J. Biogeogr. 2020, 47, 1272-1285. [CrossRef]

10. Lan, T.; Gill, S.; Bellemain, E.; Bischof, R.; Nawaz, M.A.; Lindqvist, C. Evolutionary History of Enigmatic Bears in the Tibetan Plateau-Himalaya Region and the Identity of the Yeti. Proc. R. Soc. B Biol. Sci. 2017, 284. [CrossRef] [PubMed]

11. Wilting, A.; Buckley-Beason, V.A.; Feldhaar, H.; Gadau, J.; O’Brien, S.J.; Linsenmair, K.E. Clouded Leopard Phylogeny Revisited: Support for Species Recognition and Population Division between Borneo and Sumatra. Front. Zool. 2007, 4, 15. [CrossRef] [PubMed]

12. Wilting, A.; Christiansen, P.; Kitchener, A.C.; Kemp, Y.J.M.; Ambu, L.; Fickel, J. Geographical Variation in and Evolutionary History of the Sunda Clouded Leopard (Neofelis diardi) (Mammalia: Carnivora: Felidae) with the Description of a New Subspecies from Borneo. Mol. Phylogenetics Evol. 2011, 58, 317-328. [CrossRef]

13. Patel, R.P.; Wutke, S.; Lenz, D.; Mukherjee, S.; Ramakrishnan, U.; Veron, G.; Fickel, J.; Wilting, A.; Förster, D.W. Genetic Structure and Phylogeography of the Leopard Cat (Prionailurus bengalensis) Inferred from Mitochondrial Genomes. J. Hered. 2017, 108, 349-360. [CrossRef]

14. Martins, R.F.; Schmidt, A.; Lenz, D.; Wilting, A.; Fickel, J. Human-Mediated Introduction of Introgressed Deer across Wallace's Line: Historical Biogeography of Rusa unicolor and R. timorensis. Ecol. Evol. 2017, 8, 1465-1479. [CrossRef]

15. Çilingir, F.G.; Akin Pekşen, Ç.; Ambarli, H.; Beerli, P.; Bilgin, C.C. Exceptional Maternal Lineage Diversity in Brown Bears (Ursus arctos) from Turkey. Zool. J. Linn. Soc. 2016, 176, 463-477. [CrossRef]

16. Rueness, E.K.; Naidenko, S.; Trosvik, P.; Stenseth, N.C. Large-scale genetic structuring of a widely distributed carnivore-the Eurasian lynx (Lynx lynx). PLoS ONE 2014, 9, e93675. [CrossRef] [PubMed]

17. Kitchener, A.C.; Breitenmoser-Würsten, C.; Eizirik, E.; Gentry, A.; Werdelin, L.; Wilting, A.; Yamaguchi, N. A Revised Taxonomy of the Felidae. The Final Report of the Cat Classification Task Force of the IUCN/ SSC Cat Specialist Group. Cat News Spec. Issue 2017, 11, 80 .

18. Lucena-Perez, M.; Marmesat, E.; Kleinman-Ruiz, D.; Martínez-Cruz, B.; Wẹcek, K.; Saveljev, A.P.; Seryodkin, I.V.; Okhlopkov, I.; Dvornikov, M.G.; Ozolins, J.; et al. Genomic Patterns in the Widespread Eurasian Lynx Shaped by Late Quaternary Climatic Fluctuations and Anthropogenic Impacts. Mol. Ecol. 2020, 29, 812-828. [CrossRef]

19. Breitenmoser, U.; Breitenmoser-Würsten, C.; Okarma, H.; Kaphegyi, T.; Kaphygyi, U.; Müller, U.M.; Bern, C.; Kaphegyiwallmann, U. Action Plan for the Conservation of the Eurasian Lynx in Europe; Council and Europe Publishing: Strasbourg, France, 2000; Volume 112.

20. Gugolz, D.; Bernasconi, M.V.; Breitenmoser-Würsten, C.; Wandeler, P. Historical DNA Reveals the Phylogenetic Position of the Extinct Alpine Lynx. J. Zool. 2008, 275, 201-208. [CrossRef]

21. Schmidt, K.; Kowalczyk, R.; Ozolins, J.; Männil, P.; Fickel, J. Genetic Structure of the Eurasian Lynx Population in North-Eastern Poland and the Baltic States. Conserv. Genet. 2009, 10, 497-501. [CrossRef]

22. Ratkiewicz, M.; Matosiuk, M.; Kowalczyk, R.; Konopiński, M.K.; Okarma, H.; Ozolins, J.; Männil, P.; Ornicans, A.; Schmidt, K. High Levels of Population Differentiation in Eurasian Lynx at the Edge of the Species' Western Range in Europe Revealed by Mitochondrial DNA Analyses. Anim. Conserv. 2012, 15, 603-612. [CrossRef]

23. Ratkiewicz, M.; Matosiuk, M.; Saveljev, A.P.; Sidorovich, V.; Ozolins, J.; Männil, P.; Balciauskas, L.; Kojola, I.; Okarma, H.; Kowalczyk, R.; et al. Long-Range Gene Flow and the Effects of Climatic and Ecological Factors on Genetic Structuring in a Large, Solitary Carnivore: The Eurasian Lynx. PLoS ONE 2014, 9, e115160. [CrossRef]

24. Bull, J.K.; Heurich, M.; Saveljev, A.P.; Schmidt, K.; Fickel, J.; Förster, D.W. The Effect of Reintroductions on the Genetic Variability in Eurasian Lynx Populations: The Cases of Bohemian-Bavarian and Vosges-Palatinian Populations. Conserv. Genet. 2016, 17, 1229-1234. [CrossRef]

25. Förster, D.W.; Bull, J.K.; Lenz, D.; Autenrieth, M.; Paijmans, J.L.A.; Kraus, R.H.S.; Nowak, C.; Bayerl, H.; Kuehn, R.; Saveljev, A.P.; et al. Targeted Resequencing of Coding DNA Sequences for SNP Discovery in Nonmodel Species. Mol. Ecol. Resour. 2018, 18, 1356-1373. [CrossRef]

26. Holmala, K.; Herrero, A.; Kopatz, A.; Schregel, J.; Eiken, H.G.; Hagen, S.B. Genetic Evidence of Female Kin Clusters in a Continuous Population of a Solitary Carnivore, the Eurasian lynx. Ecol. Evol. 2018, 8, 10964-10975. [CrossRef] [PubMed]

27. Krojerová-Prokešová, J.; Turbaková, B.; Jelenčič, M.; Bojda, M.; Kutal, M.; Skrbinšek, T.; Koubek, P.; Bryja, J. Genetic Constraints of Population Expansion of the Carpathian Lynx at the Western Edge of Its Native Distribution Range in Central Europe. Heredity (Edinburgh) 2019, 122, 785-799. [CrossRef]

28. Mueller, S.A.; Reiners, T.E.; Middelhoff, T.L.; Anders, O.; Kasperkiewicz, A.; Nowak, C. The Rise of a Large Carnivore Population in Central Europe: Genetic Evaluation of Lynx Reintroduction in the Harz Mountains. Conserv. Genet. 2020, 21, 577-587. [CrossRef]

29. Herrero, A.; Klütsch, C.F.C.; Holmala, K.; Maduna, S.N.; Kopatz, A.; Eiken, H.G.; Hagen, S.B. Genetic Analysis Indicates Spatial-Dependent Patterns of Sex-Biased Dispersal in Eurasian lynx in Finland. PLoS ONE 2021, 16, e246833. [CrossRef]

30. Fickel, J.; Hauffe, H.C.; Pecchioli, E.; Soriguer, R.; Vapa, L.; Pitra, C. Cladogenesis of the European Brown Hare (Lepus europaeus Pallas, 1778). Eur. J. Wildl. Res. 2008, 54, 495-510. [CrossRef]

31. Sommer, R.S.; Nadachowski, A. Glacial Refugia of Mammals in Europe: Evidence from Fossil Records. Mamm. Rev. 2006, 36, 251-265. [CrossRef] 
32. Cooper, S.J.B.; Hewitt, G.M. Nuclear DNA Sequence Divergence between Parapatric Subspecies of the Grasshopper Chorthippus parallelus. Insect Mol. Biol. 1993, 2, 185-194. [CrossRef] [PubMed]

33. Bilgin, R. Back to the Suture: The Distribution of Intraspecific Genetic Diversity in and around Anatolia. Int. J. Mol. Sci. 2011, 12, 4080-4103. [CrossRef]

34. Arslan, Y.; Demirtaş, S.; Herman, J.S.; Pustilnik, J.D.; Searle, J.B.; Gündüz, I. The Anatolian Glacial Refugium and HumanMediated Colonization: A Phylogeographical Study of the Stone Marten (Martes foina) in Turkey. Biol. J. Linn. Soc. 2020, 129, 470-491. [CrossRef]

35. Cömert, N.; Carlı, O.; Dinçtürk, H.B. The Missing Lynx of Eurasia at Its Southern Edge: A Connection to the Critically Endangered Balkan lynx. Mitochondrial DNA Part A DNA Mapp. Seq. Anal. 2018, 29, 1269-1275. [CrossRef] [PubMed]

36. İbiş, O.; Özcan, S.; Kırmanoğlu, C.; Keten, A.; Tez, C. Genetic Analysis of Turkish Lynx (Lynx lynx) Based on Mitochondrial DNA Sequences. Russ. J. Genet. 2019, 55, 1426-1437. [CrossRef]

37. Mengüllüoğlu, D.; Fickel, J.; Hofer, H.; Förster, D.W. Non-Invasive Faecal Sampling Reveals Spatial Organization and Improves Measures of Genetic Diversity for the Conservation Assessment of Territorial Species: Caucasian lynx as a Case Species. PLoS ONE 2019, 14, e216549. [CrossRef] [PubMed]

38. Wu, Y.; Xu, H.; Li, D.; Xie, M.; Wu, J.; Wen, A.; Wang, Q.; Zhu, G.; Ni, Q.; Zhang, M.; et al. Complete Mitochondrial Genome and Phylogenetic Analysis of a Chinese Eurasian Lynx (Lynx Lynx). Mitochondrial DNA Part B Resour. 2018, 3, 1174-1175. [CrossRef] [PubMed]

39. Mengüllüoğlu, D.; Ambarlı, H.; Berger, A.; Hofer, H. Foraging Ecology of Eurasian lynx Populations in Southwest Asia: Conservation Implications for a Diet Specialist. Ecol. Evol. 2018, 8, 9451-9463. [CrossRef] [PubMed]

40. Shevchenko, L.S.; Peskov, V.N. Morphological variability and intraspecies systematics of European lynx, Lynx lynx. Zbirnyk Prac. Zool. Мuzeju 2007, 39, 81-99. (In Russian)

41. Mengüllüoğlu, D.; Edwards, S.; Hofer, H.; Berger, A. Female and male Eurasian lynx have distinct spatial tactics at different life-history stages in a high-density population. Ecol. Evol. 2021, 11, 10342-10445. [CrossRef]

42. Weidong, B. Eurasian lynx in China-present status and conservation challenges. Cat News Spec. Issue 2010, 5, $22-25$.

43. Ryabinina, M.A.; Esipov, A.V. "K Pitaniyu Turkestanskoy Rysi" [On the Diet of the Turkestan lynx]. In Ekologiya Rasteniy $i$ Zhivotnykh Zapovednikov Uzbekistana; Ecology of Plants and Animals in the Reserves of Uzbekistan; Academy of Sciences of UzSSR: Tashkent, Uzbekistan, 1983; pp. 91-93.

44. Loukarevskiy, V.S. Information on the fauna and recent status of some populations are large mammals in the Kugitang Range (Eastern Turkmenistan). Lutreola 1996, 7, 19-21.

45. Lever, C. Handbook of the Mammals of the World: Vol. 1: Carnivores. Zool. J. Linn. Soc. 2010, 160, 827-828. [CrossRef]

46. Kaczensky, P.; Rustamov, E.; Karryeva, S.; Iankov, P.; Hudaykuliev, N.; Saparmyadov, J.; Veyisov, A.; Shestopal, A.A.; Mengliev, S.; Hojamyradov, H.; et al. 2019 Rapid Assessments of Wildlife in Turkmenistan 2018; NINA Report 1696; Norwegian Institute for Nature Research: Trondheim, Norway, 2019.

47. Ning, Y.; Liu, H.; Jiang, G.; Ma, J. Phylogenetic Relationship of Eurasian Lynx (Lynx lynx) Revealed by Complete Mitochondrial Genome. Mitochondrial DNA 2016, 27, 3477-3478. [CrossRef]

48. Fortes, G.G.; Paijmans, J.L.A. Analysis of Whole Mitogenomes from Ancient Samples. In Whole Genome Amplification: Methods and Protocols; Springer: New York, NY, USA, 2015; pp. 179-195. [CrossRef]

49. Maricic, T.; Whitten, M.; Pääbo, S. Multiplexed DNA Sequence Capture of Mitochondrial Genomes Using PCR Products. PLoS ONE 2010, 5, e14004. [CrossRef]

50. Paijmans, J.L.A.; Fickel, J.; Courtiol, A.; Hofreiter, M.; Förster, D.W. Impact of Enrichment Conditions on Cross-Species Capture of Fresh and Degraded DNA. Mol. Ecol. Resour. 2016, 16, 42-55. [CrossRef] [PubMed]

51. Martin, M. Cutadapt Removes Adapter Sequences from High-Throughput Sequencing Reads. EMBnet J. 2011, 17, 10. [CrossRef]

52. Bolger, A.M.; Lohse, M.; Usadel, B. Trimmomatic: A Flexible Trimmer for Illumina Sequence Data. Bioinformatics 2014, 30, 2114-2120. [CrossRef]

53. Magoč, T.; Salzberg, S.L. FLASH: Fast Length Adjustment of Short Reads to Improve Genome Assemblies. Bioinformatics 2011, 27, 2957-2963. [CrossRef] [PubMed]

54. Li, H.; Durbin, R. Fast and Accurate Short Read Alignment with Burrows-Wheeler Transform. Bioinformatics 2009, 25, 1754-1760. [CrossRef] [PubMed]

55. Li, H.; Handsaker, B.; Wysoker, A.; Fennell, T.; Ruan, J.; Homer, N.; Marth, G.; Abecasis, G.; Durbin, R. The Sequence Alignment/Map Format and SAMtools. Bioinformatics 2009, 25, 2078-2079. [CrossRef]

56. Kearse, M.; Moir, R.; Wilson, A.; Stones-Havas, S.; Cheung, M.; Sturrock, S.; Buxton, S.; Cooper, A.; Markowitz, S.; Duran, C.; et al. Geneious Basic: An Integrated and Extendable Desktop Software Platform for the Organization and Analysis of Sequence Data. Bioinformatics 2012, 28, 1647-1649. [CrossRef]

57. Drummond, A.J.; Suchard, M.A.; Xie, D.; Rambaut, A. Bayesian Phylogenetics with BEAUti and the BEAST 1.7. Mol. Biol. Evol. 2012, 29, 1969-1973. [CrossRef]

58. Rambaut, A.; Drummond, A.J.; Suchard, M. Tracer v1.6: MCMC Trace Analysis Package; Institute of Evolutionary Biology, Department of Computer Science: Edinburgh, UK, 2013.

59. Bouckaert, R.; Heled, J.; Kühnert, D.; Vaughan, T.; Wu, C.H.; Xie, D.; Suchard, M.A.; Rambaut, A.; Drummond, A.J. BEAST 2: A Software Platform for Bayesian Evolutionary Analysis. PLoS Comput. Biol. 2014, 10, e1003537. [CrossRef] 
60. Leigh, J.W.; Bryant, D. POPART: Full-Feature Software for Haplotype Network Construction. Methods Ecol. Evol. 2015, 6, 1110-1116. [CrossRef]

61. Werdelin, L. The Evolution of Lynxes. Ann. Zool. Fenn. 1981, 18, 37-71.

62. Alves, P.C.; Melo-Ferreira, J.; Freitas, H.; Boursot, P. The Ubiquitous Mountain Hare Mitochondria: Multiple Introgressive Hybridization in Hares, Genus Lepus. Philos. Trans. R. Soc. B Biol. Sci. 2008, 363, 2831-2839. [CrossRef]

63. Goodman, S.J.; Barton, N.H.; Swanson, G.; Abernethy, K.; Pemberton, J.M. Introgression through Rare Hybridization: A Genetic Study of a Hybrid Zone between Red and Sika Deer (Genus Cervus) in Argyll, Scotland. Genetics 1999, 152, 355-371. [CrossRef] [PubMed]

64. Tate, M.L.; Mathias, H.C.; Fennessy, P.F.; Dodds, K.G.; Penty, J.M.; Hill, D.F. A New Gene Mapping Resource: Interspecies Hybrids between Pere David's Deer (Elaphurus davidianus) and Red Deer (Cervus elaphus). Genetics 1995, 139, 1383-1391. [CrossRef] [PubMed]

65. Lericolais, G.; Popescu, I.; Guichard, F.; Popescu, S.M.; Manolakakis, L. Water-Level Fluctuations in the Black Sea since the Last Glacial Maximum. In The Black Sea Flood Question: Changes in Coastline, Climate, and Human Settlement; Springer Science and Business Media: New York, NY, USA, 2007; pp. 437-452. [CrossRef]

66. Okay, S.; Jupinet, B.; Lericolais, G.; Çifçi, G.; Morigi, C. Morphological and Stratigraphic Investigation of a Holocene Subaqueous Shelf Fan, North of the İstanbul Strait in the Black Sea. Turk. J. Earth Sci. 2011, 20, 258-305. [CrossRef]

67. Meeting Report of the Large Carnivore's Session at the Forum Carpaticum 2018, Eger, Hungary. Available online: http: //www.carpathianconvention.org/eventdetailothers/events/forum-carpaticum-2018-large-carnivores-session.html (accessed on 30 July 2021).

68. Senn, H.V.; Ghazali, M.; Kaden, J.; Barclay, D.; Harrower, B.; Campbell, R.D.; Macdonald, D.W.; Kitchener, A.C. Distinguishing the victim from the threat: SNP-based methods reveal the extent of introgressive hybridization between wildcats and domestic cats in Scotland and inform future in situ and ex situ management options for species restoration. Evol. Appl. 2019, 12, 399-414. [CrossRef] [PubMed]

69. Stamatis, C.; Suchentrunk, F.; Moutou, K.A.; Giacometti, M.; Haerer, G.; Djan, M.; Vapa, L.; Vukovic, M.; Tvrtković, N.; Sert, H.; et al. Phylogeography of the Brown Hare (Lepus europaeus) in Europe: A Legacy of South-Eastern Mediterranean Refugia? J. Biogeogr. 2009, 36, 515-528. [CrossRef]

70. Ashrafzadeh, M.R.; Djan, M.; Szendrei, L.; Paulauskas, A.; Scandura, M.; Bagi, Z.; Ilie, D.E.; Kerdikoshvili, N.; Marek, P.; Soos, N.; et al. Large-Scale Mitochondrial DNA Analysis Reveals New Light on the Phylogeography of Central and Eastern-European Brown Hare (Lepus europaeus Pallas, 1778). PLoS ONE 2018, 13, e204653. [CrossRef]

71. Şekercioĝlu, Ç.H.; Anderson, S.; Akçay, E.; Bilgin, R.; Can, Ö.E.; Semiz, G.; Tavşanoĝlu, Ç.; Yokeş, M.B.; Soyumert, A.; Ipekdal, K.; et al. Turkey's Globally Important Biodiversity in Crisis. Biol. Conserv. 2011, 144, 2752-2769. [CrossRef]

72. İ̉iş, O.; Aksöyek, E.; Özcan, S.; Keten, A.; Yorulmaz, T.; Tez, C. Genetic Analysis of the Turkish Gray Wolf (Canis lupus) Based on Partial Mitochondrial DNA Sequences. Vertebr. Zool. 2016, 66, 427-435.

73. Telcioğlu, M.; İbiş, O.; Aksöyek, E.; Özcan, S.; Moradi, M.; Gürkan, Ö.F.; Tez, C. Genetic Analysis of Iranian and Turkish Red Foxes (Vulpes vulpes) Based on Mitochondrial DNA (D-Loop) Sequences. Ethol. Ecol. Evol. 2019, 31, 568-582. [CrossRef]

74. İbiş, O.; Tez, C. Phylogenetic Status and Genetic Diversity of the Turkish Marbled Polecat Vormela peregusna, (Mustelidae: Carnivora: Mammalia), Inferred from the Mitochondrial Cytochrome b Gene. Vertebr. Zool. 2014, 64, 285-294.

75. Gündüz, I.; Jaarola, M.; Tez, C.; Yeniyurt, C.; Polly, P.D.; Searle, J.B. Multigenic and Morphometric Differentiation of Ground Squirrels (Spermophilus, Scuiridae, Rodentia) in Turkey, with a Description of a New Species. Mol. Phylogenetics Evol. 2007, 43, 916-935. [CrossRef]

76. Gündüz, I.; Rambau, R.V.; Tez, C.; Searle, J.B. Mitochondrial DNA Variation in the Western House Mouse (Mus musculus domesticus) Close to Its Site of Origin: Studies in Turkey. Biol. J. Linn. Soc. 2005, 84, 473-485. [CrossRef]

77. Kankiliç, T.; Özüt, D.; Gürler, Ş.; Kence, M.; Bozkaya, F.; Kence, A. Rediscovery of a New Mountain Gazelle Population and Clarification of Taxonomic Status of the Genus Gazella in Turkey Using MtDNA Sequencing. Folia Zool. 2012, 61, $129-137$. [CrossRef]

78. Karataş, A.; Bulut, Ş.; Akbaba, B. Camera Trap Records Confirm the Survival of the Leopard (Panthera pardus L.; 1758) in Eastern Turkey (Mammalia: Felidae). Zool. Middle East 2021. [CrossRef]

79. Sedalischev, V.T.; Odnokurtsev, V.A.; Ohlopkov, I.M. The materials on ecology of the lynx (Lynx lynx, 1758) in Yakutia. News Samara Sci. Cent. Russ. Acad. Sci. 2014, 16, 175-182. (In Russian)

80. Hailer, F.; Kutschera, V.E.; Hallström, B.M.; Klassert, D.; Fain, S.R.; Leonard, J.A.; Arnason, U.; Janke, A. Nuclear Genomic Sequences Reveal That Polar Bears Are an Old and Distinct Bear Lineage. Science 2012, 336, 344-347. [CrossRef] 